\title{
EN MEMORIA: MIGUEL A. LUGO LÓPEZ 1921-2005
}

\author{
José A. Arroyo-Aguilú, Wanda I. Lugo y Jaime Escudero \\ J. Agric. Univ. P.R. 93(3-4):281-299 (2009)
}

Miguel A. Lugo López falleció en junio de 2005 en Isabela, Puerto Rico. Le sobrevive su esposa la Sra. Aurora de Menkini de Lugo, su hijo Peter, sus nietos y su biznieta.

El doctor Lugo López nació el 21 de julio de 1921 en Mayagüez, Puerto Rico, ciudad donde también cursó estudios elementales y superiores. En 1943 se graduó con honores de Bachiller en Ciencias Agrícolas, con una concentración en Agronomía, del Colegio de Agricultura y Artes Mecánicas de la Universidad de Puerto Rico en Mayagüez. Profesionalmente se inició trabajando como Auxiliar de Investigaciones en la Estación Experimental Federal en Mayagüez. Sin embargo, pronto partió hacia la Universidad de Cornell en Ithaca, Nueva York, donde en 1945 obtuvo el grado de Maestro en Ciencias, especializado en Ciencias del Suelo. Allí continuó estudios post-graduados hasta 1946.

A su regreso a Puerto Rico sirvió por dos años como Catedrático Auxiliar en el Colegio de Agricultura y Artes Mecánicas de Mayagüez. De allí pasó a ocupar el puesto de Científico Auxiliar de Suelos en la Estación Experimental Agrícola (EEA) de la Universidad de Puerto Rico, en Río Piedras. Posteriormente continuó sus estudios graduados y en 1950 obtuvo el grado de Doctor en Filosofía, en Ciencias del Suelo, en la Universidad de Cornell. Del 1950 al 1957 fue Científico Asociado de Suelos y Director Interino del Departamento de Suelos en la EEA en Río Piedras. Del 1957 al 1960 trabajó en la Subestación de Gurabo como Científico Asociado de Suelos y Científico de Suelos a Cargo; del 1960 al 1961 ocupó el puesto de Director Auxiliar de la EEA a cargo de la Subestación de Gurabo.

De la Subestación de Gurabo pasó a la EEA en Río Piedras, donde ocupó los puestos de Director Auxiliar, Director Interino, Director Asociado y Científico de Suelos. Del 1969 al 1972 fue Profesor y Científico de Suelos, además de Director de la Oficina de Programas y Planes y Decano Asociado del Colegio de Ciencias Agrícolas, en el Recinto Universitario de Mayagüez (RUM). Ocupó el puesto de Decano de Estudiantes del RUM del 1972 al 1974. En 1974 regresa a la investigación como Científico de Suelos y Líder del Proyecto de Investigaciones en 
Suelos Tropicales, un proyecto colaborativo entre la Universidad de Puerto Rico, la Universidad de Cornell y la Agencia para el Desarrollo Internacional (AID).

El doctor Lugo López se retiró de la Universidad de Puerto Rico en 1977, tras haber prestado servicios distinguidos en la investigación de suelos tropicales, en la docencia y la administración universitaria y como consultor agrícola. Posteriormente trabajó con la Universidad de Cornell en calidad de Consultor de Suelos Tropicales. Del 1981 al 1985 fue Consultor de la firma Servicios Técnicos del Caribe de San Juan, y a partir de 1984, Colaborador de la Estación de Investigaciones en Agricultura Tropical (TARS, por sus siglas en inglés) en Mayagüez. Hasta poco antes de su muerte el doctor Lugo López fue Profesor y Científico de Suelos Ad Honorem de la Estación Experimental Agrícola, Colegio de Ciencias Agrícolas.

En la Facultad de Agricultura, fue Profesor de Suelos y preparó importantes cursos en el manejo de los suelos tropicales. En varias ocasiones fue representante de la Escuela Graduada y participó en comités graduados de Maestría en Ciencias. Además, editó innumerables tesis de maestría de estudiantes graduados.

Durante sus años ocupando posiciones administrativas cooperó en el desarrollo de mejores relaciones de trabajo entre la EEA y la Facultad de Agricultura. Uno de sus logros más importantes fue ayudar a que se estableciera, para los Investigadores de la EEA, rango académico y sueldo equivalente al de los Profesores de la Facultad de Agricultura. Como Decano de Estudiantes, cooperó en el desarrollo de normas para fortalecer el programa de becas para estudiantes graduados fuera de Puerto Rico, además de obtener otros importantes logros. Organizó la Oficina de Programas y Planes y cooperó en el desarrollo del Plan Maestro de todas las unidades del Colegio de Ciencias Agrícolas. Junto al Dr. Vicente Chandler, preparó la propuesta en Suelos Tropicales con la Universidad de Cornell, financiada por la AID. Preparó otra propuesta con la AID para fortalecer las capacidades de la Universidad de Puerto Rico en la enseñanza y la investigación en Suelos Tropicales. Esta fue la base para obtener otras ayudas y contratos para investigación en diversos cultivos.

Entre sus actividades como Consultor del Colegio de Ciencias Agrícolas podemos mencionar su participación en 1980, a solicitud del Rector, en la propuesta para el desarrollo del Centro Norte Sur para Intercambio Científico, Tecnológico y Cultural. Además, en 1982, preparó una propuesta para establecer el "Caribbean Agricultural Research and Training Center" en el RUM. Ese mismo año participó en una misión del Gobierno de Puerto Rico para establecer vínculos entre Puerto Rico y Jamaica relacionados con el Programa de la Iniciativa de la 
Cuenca del Caribe del Presidente Reagan. Además, participó en diversas evaluaciones de programas de la Estación Experimental y del Colegio de Ciencias Agrícolas. Evaluó manuscritos de investigación y extensión, y preparó numerosas propuestas para el Colegio de Ciencias Agrícolas.

El doctor Lugo López fue autor o coautor de más de 220 trabajos científicos en su especialidad, los cuales fueron publicados tanto en revistas locales como internacionales. Algunos de éstos se mencionan más adelante. Fue un científico reconocido mundialmente por sus investigaciones en los suelos tropicales, especialmente en la clasificación taxonómica de los suelos de Puerto Rico e Islas Vírgenes y en el manejo y la fertilidad de los suelos. El doctor Lugo López estudió la relación entre el manejo de los suelos y la productividad, concluyendo que bajo manejo intensivo con tecnología adecuada, los suelos de Puerto Rico (y los suelos de los trópicos) pueden ser la base para una agricultura permanente y eficiente. En el marco profesional, el doctor Lugo López podría ser clasificado como uno de los científicos puertorriqueños que más ha contribuido al conocimiento de los suelos tropicales y su manejo.

Fue miembro de las Sociedades de Honor Phi Kappa Phi, Gamma Sigma Delta, Alpha Phi Omega, New York Academy of Sciences y American Society for the Advancement of Science. Perteneció al Colegio de Agrónomos, a la Sociedad Puertorriqueña de Ciencias Agrícolas (SOPCA), a la American Society of Agronomy, a la Soil Science Society of America, a la Soil Conservation Society of America y a la Caribbean Food Crops Society (CFCS). Entre los reconocimientos que recibió el doctor Lugo López podemos mencionar Agrónomo del Año, en 1965; Agrónomo más Distinguido del Año, en 1968; Honorary Life Member de la CFCS, en 1965, y de la National Service Fraternity Alpha Phi Omega. En 1989 el Senado Académico del Recinto Universitario de Mayagüez le honró otorgándole el grado de Profesor Emérito de la Universidad de Puerto Rico. Posteriormente, en 1996, se le reconoció como Ex Alumno Distinguido de la Universidad de Puerto Rico. En 2008, la Caribbean Food Crops Society le honró dándole su nombre y el de su esposa a un programa de becas para estudiantes graduados (The Miguel and Aurora Lugo Caribbean Food Crops Society Student Scholar). Además, la Facultad de Ciencias Agrícolas le dio su nombre al premio que se le otorga a su mejor estudiante de bachillerato durante los actos de graduación.

Viajó extensamente en este hemisferio en calidad de consultor y para participar en congresos, simposios y reuniones. Sus aportaciones a la agricultura tropical, especialmente en los suelos tropicales, van más allá de nuestra Isla. En países como la República Dominicana, Jamaica, Haití, Bolivia, Panamá, Costa Rica, Guyana y otros, sus investigaciones y sus logros recibieron reconocimientos extraordinarios. 
Fue inspiración para científicos jóvenes ya que hasta el final de sus días buscaba la interacción con compañeros en diversos temas tanto de índole humanístico, política pública agraria y ciencias del suelo. Sirvió de mentor a profesores e investigadores jóvenes, exhortándolos a revisar literatura, desarrollar y organizar ideas y a publicar los trabajos científicos. Sus diálogos ayudaban a crear espacio y formar visión en cuanto al rol de cada profesional en la agricultura puertorriqueña. Siempre tuvo palabras positivas y alentadoras para todos por igual. Fue un gran compañero de trabajo cuya amistad trascendio generaciones en el Colegio de Ciencias Agrícolas, la Estación Experimental Agrícola y la Universidad de Puerto Rico.

\section{PUBLICACIONES}

Bonnet, J. A., P. Tirado-Sulsona y M. A. Lugo-López, 1949. Attempt to reclaim with chemicals a salty clay in Puerto Rico. J. Agric. Univ. P.R. 33 (2):75-84.

Lugo-López, M. A. et al., 1950. Aids used in interpreting soils data at the University of Puerto Rico. Soil Science in the Caribbean, Caribbean Commission, Trinidad.

Lugo-López, M. A. et al., 1950. Laboratory methods for soil and plant analysis used in the Agricultural Experiment Station, University of Puerto Rico, Soil Science in the Caribbean, Caribbean Commission, Trinidad.

Lugo-López, M. A. et al., 1950. Field methods of soil survey in Puerto Rico, Soil Science in the Caribbean, Caribbean Commission, Trinidad.

Bonnet, J. A., F. Abruña y M. A. Lugo-López, 1950. Trash disposal and its relation to cane yield, and soil and water losses. J. Agric. Univ. P.R. 34 (3):286-93.

Bonnet, J. A. y M. A. Lugo-López, 1950. Relative erosiveness of Puerto Rico soils. J. Agric. Univ. P.R. 34 (3):294-307.

Bonnet, J. A. y M. A. Lugo-López, 1950. Soil studies in the projected Coamo irrigation area. Est. Exp. Agric. Univ. P.R., Bol. 88.

Bonnet, J. A., M. A. Lugo-López y F. Abruña 1951. Cation exchange capacity of some tropical soils of Puerto Rico. J. Agric. Univ. P.R. 35 (2):49-56.

Lugo-López, M. A., 1951. Características del suelo que determinan su resistencia o susceptibilidad a la erosión. Revista de Agricultura de Puerto Rico 42(12):92-98.

Lugo-López, M. A., 1951. Functional relationship between moisture at several equilibrium points and the clay content of tropical soils. J. Agric. Univ. P.R. 35 (2):66-70.

Lugo-López, M. A. y J. A. Bonnet, 1951. Utilization of organic soils in Puerto Rico. J. Agric. Univ. P.R. 35 (2):57-65. 
Martínez, M. B. y M. A. Lugo-López, 1951. Plans for research on the effects of subsoiling and subsoil fertilization on sugarcane fields. Sugar J. 14:36-42.

Bonnet, J. A. y M. A. Lugo-López, 1952. The rate of infiltration of lateritic soils. J.Agric. Univ. P.R. 36 (2):161-166.

Lugo-López, M.A., 1952. Acondicionamiento de los suelos para la producción de alimentos. Revista de Agricultura de Puerto Rico 43(1):60-75.

Lugo-López, M. A., 1952. Drainage practices and problems in Puerto Rico. Agric. Eng. Pp 430.

Lugo-López, M.A., 1952. Comparative value of various methods of approximating the permanent wilting percentage. J. Agric. Univ. P.R. 36 (2):122-133.

Lugo-López, M. A., 1952. Available water capacity of the surface layer of various soils from the arid and semiarid region of Puerto Rico. J. Agric. Univ. P.R. $36(2): 134-140$.

Lugo-López, M. A., 1952. Moisture characteristics of some soils of Puerto Rico where sugarcane is grown. Sugar J. 15 (6):29-32.

Lugo-López, M. A., F. Abruña y J. Roldán, 1952. Evaluation of the lime requirement of tropical soils in terms of other soil characteristics. J. Agric. Univ. P.R. $36(2): 155-160$.

Lugo-López, M. A. y R. Grant, 1952. Preharvest foliage sprays of sugarcane with 2, 4-D. J. Agric. Univ. P.R. 36 (3):187-193.

Lugo-López, M. A., P. Landrau, Jr., y G. Samuels, 1952. The handling of sugarcane trash, II: Effects of various practices on soil properties. J. Agric. Univ. P.R. 36(3):246-254.

Lugo-López, M. A. y M. B. Martínez, 1952. Fertilizer placement affects sugarcane yields. Agric. Eng. Pp 548.

Lugo-López, M. A. y M. B. Martínez, 1952. Influence of subsurface tillage practices upon the infiltration capacity of a claypan soil planted to sugarcane. Sugar J. 14 (12):54-56.

Lugo-López, M. A. y M. B. Martínez, 1952. Drainage of sugarcane fields in eastcentral Puerto Rico. Sugar J. 15 (5):14-20.

Lugo-López, M. A., M. B. Martínez y A. R. Riera, 1952. Morphological and physicochemical properties of various tropical soils from east central Puerto Rico.J. Agric. Univ. P.R. 36 (2):167-178.

Martínez, B. y M. A. Lugo-López, 1952. The influence of subsoil fertilization on sugarcane yields. Sugar J. 15 (7):24-27.

Martínez, M. B. y M. A. Lugo-López, 1952. Tillage Tests, I: Effect of subsoiling and mole drainage upon the minimum infiltration capacity of a heavy claypan soil of the tropics. J. Agric. Univ. P.R. 36 (2):179-185. 
Samuels, G., P. Landrau Jr. y M. A. Lugo-López, 1952. Handling of sugarcane trash: its effects on yields and soil. Sugar 47 (4):47-49.

Samuels, B., M. A. Lugo-López y P. Landrau, Jr., 1952. Influence of the handling of sugarcane trash on yields and soil properties. Soil Sci. 74 (3):207-215.

Samuels, G., M. A. Lugo-López y P. Landrau Jr., 1952. The influence of fertilizers on the sucrose content of sugarcane. Sugar 42 (11):49-51.

Samuels, G., M. A. Lugo-López y P. Landrau, Jr., 1952. Factors affecting the sucrose content of sugarcane: Fertilizers. J. Agric. Univ. P.R. 36(3):194-202.

Bonnet, J. A. y M. A. Lugo-López, 1953. Effect of different quantities of velvetbean green manure on corn yields in Puerto Rico. J. Agric. Univ. P.R. 37 (1):96-101.

Hernández-Medina, E., M. A. Lugo-López y H. R. Cibes-Viadé, 1953. The beneficial effect of filter press cake on pineapple yields under field conditions. J. Agric. Univ. P.R. 37 (3):206-212.

Lugo-López, M. A., 1953. Moisture relationships of Puerto Rican soils. Est. Exp. Agric., Univ. P.R. Tech. Paper 9.

Lugo-López, M. A., J. A. Bonnet y J. García, 1953. The soils of the island of Vieques. Est. Exp. Agric., Univ. P.R. Bol. 108.

Lugo-López, M. A., B. G. Capó, F. Aróstegui y A. Riollano, 1953. Intercropping sugarcane with food crops. J. Agric. Univ. P.R. 37 (3):171-182.

Lugo-López, M. A., E. Hernández-Medina, H. R. Cibes-Viadé y J. Vicente-Chandler, 1953. The effect of filter-press cake on the physical and chemical properties of soils. J. Agric. Univ. P.R. 37 (3):213-223.

Lugo-López, M. A., G. Samuels y R. Grant, 1953. Failure of preharvest foliage sprays with 2,4-D and maleic hydrazide to affect the sucrose content of sugarcane. J. Agric. Univ. P.R. 37 (1):44-51.

Lugo-López, M. A., G. Samuels y F. Méndez, 1953. Factors affecting the sucrose content of sugarcane: III. Varieties. J. Agric. Univ. P.R. 37 (1):28-34.

Martínez, M. B. y M. A. Lugo-López, 1953. Influence of subsoil shattering and fertilization upon sugarcane production and soil infiltration capacity. Soil Sci. 75 (4):307-315.

Martínez, M. B. y M. A. Lugo- López, 1953. Tillage Tests II: The beneficial effect of subsoil fertilization on sugarcane yields. J. Agric. Univ. P.R. 37 (1):35-43.

Landrau, P., Jr., M. A. Lugo-López, G. Samuels y S. Silva, 1954. Leaving sugarcane trash undisturbed on a lateritic soil compares favorably with currently used trash-disposal methods. J. Agric. Univ. P.R. 38 (1):1-8.

Lugo-López, M. A., 1954. The effect of soil conditions on the sucrose content of sugarcane. J.Agric. Univ. P.R. 38 (3):132-146.

Lugo-López, M. A., 1954. Influence of filter-press cake on pineapple yields and soil properties. Soil Sci. 78 (4):257-265. 
Lugo-López, M. A., J. A. Bonnet, E. Hernández-Medina, P. Landrau Jr. y G. Samuels. October 1954. Soil organic matter levels and crop yields in Puerto Rico. Soil Sci. Soc. Amer: Proc. 18 (4):489-493.

Lugo-López, M. A. y B. G. Capó, 1954. The effect of elevation on the sucrose content of sugarcane. J. Agric. Univ. P.R. 38 (3):128-131.

Lugo-López, M. A. y B. G. Capó, 1954. The effect of weather and climate on the sucrose content of sugarcane. J. Agric. Univ. P.R. 38 (4):149-169.

Martínez, M. B. y M. A. Lugo-López, 1954. Lack of residual influence from subsoil fertilization of a sugarcane plant crop upon the succeeding ratoon crop. $J$. Agric. Univ. P.R. 38 (3):123-127.

Lugo-López, M. A. y G. Acevedo, 1956. Effects of tractor-traffic compaction on the physical properties of an irrigated soil in southwestern Puerto Rico. J. Agric. Univ. P.R. 40 (4):235-244.

Lugo-López, M. A., E. Hernández-Medina y P. Landrau, Jr., 1956. Differential response of some tropical soils to additions of organic matter. J. Agric. Univ. P.R. 40 (1):70-77.

Lugo-López, M. A. y P. Landrau, Jr., 1956. Practical evaluation of garbage compost as a fertilizer under conditions in Puerto Rico. J. Agric. Univ. P.R. 40 (2):110-117.

Bonnet, J. A., M. A. Lugo-López y M. Rico-Ballester, 1957. Effect of incorporating organic materials into a clay soil of Lajas Valley on the yields of food crops. J. Agric. Univ. P.R. 41 (3):173-178.

Hernández-Medina, E., A. Cruz-Miret y M. A. Lugo-López, 1957. Residual effect of filter-press cake application on pineapple yields. J. Agric. Univ. P.R. 41 (3):197-201.

Lugo-López, M. A., J. A. Bonnet, A. S. Amy y R. Pérez-Escolar, 1957. Effect of soil-structure stabilizers on the production of tobacco plants in the seedbeds. $J$. Agric. Univ. P.R. 41 (3):189-196.

Lugo-López, M. A., J. A. Bonnet y R. Pérez-Escolar, 1957. Effect of lime and soil conditioners on crop yields and soil aggregation. J.Agric. Univ. P.R. 41 (3):179-188.

Lugo-López, M. A., J. A. Bonnet, M. Rico-Ballester y C. Acevedo, 1957. Lack of response of some food crops to the application of synthetic soil conditioners to a clay soil in Lajas Valley. J. Agric. Univ. P.R. 41 (3):167-172.

Lugo-López, M. A., H. A. Manfrinato y E. J. Brenes, 1957. Characterization of a buried Latosol from northern Puerto Rico. J. Agric. Univ. P.R. 41 (2):119-126.

Lugo-López, M. A. y R. Pérez-Escolar, 1957. La materia orgánica en los suelos de la zona cafetalera de Puerto Rico. Revista de Agricultura de Puerto Rico 64 (2):85-92.

Pérez-Escolar, R. y M. A. Lugo-López, 1957. The effect of synthetic soil conditioners on soil-aggregate stability and the production of potatoes and stringless beans. J. Agric. Univ. P.R. 41 (2):127-133. 
Bonnet, J. A., M. A. Lugo-López, J. Roldán y R. Pérez-Escolar, 1958. Effect of lime and phosphate-bearing materials on sugarcane yields. J. Agric. Univ. P.R. $42(1): 1-6$.

Bonnet, J. A., A. R. Riera y M. A. Lugo-López, 1958. Lack of response of old coffee trees grown in Alonso clay to lime and phosphatic fertilization. J. Agric. Univ. P.R. 42 (3):161-167.

Hernández-Medina, E. y M. A. Lugo-López, 1958. Observations on the boronmanganese relationships in soybean and corn plants. J. Agric. Univ. P.R. 42 (1):27-34.

Hernández-Medina, E. y M. A. Lugo-López, 1958. Effects of the calcium-boron relationship on growth and production of the pineapple plant. J. Agric. Univ. P.R. 42 (4):207-223.

Lugo-López, M. A., E. Hernández-Medina y G. Acevedo, 1958. Response of some tropical soils and crops of Puerto Rico to applications of lime. Est. Exp. Agric., Univ. P.R. Tech. Paper 28.

Lugo-López, M. A., P. Landrau, Jr. y B. G. Capó, 1958. The response of Hegari sorghum to lime applications of various levels. J. Agric. Univ. P.R. 42 (4):233238 .

Acevedo, G., M. A. Lugo-López y J. Ortiz-Vélez, 1959. Occurrence of soil tumors northeast of the Guánica Lagoon, Lajas Valley, P.R. J. Agric. Univ. P.R. 43 (2): 103-115.

Lugo-López, M. A. y J. Juárez, Jr., 1959. Evaluation of the effects of organic matter and other soil characteristics upon the aggregate stability of some tropical soils. J. Agric. Univ. P.R. 43 (4):268-272.

Lugo-López, M. A. y R. Pérez-Escolar, 1959. Hydraulic conductivity of subsoils of Lajas Valley. J. Agric. Univ. P.R. 43 (4):273-277.

Lugo-López, M. A. y R. Pérez-Escolar, G. Acevedo y J. Juárez, Jr., 1959. Nature and properties of major soils of Lajas Valley. Est. Exp. Agric., Univ. P.R. Bol. 149 .

Lugo-López, M. A., 1960. Pore size and bulk density as mechanical soil factors impeding root development. J. Agric. Univ. P.R. 44 (1):40-44.

Barbosa Cupeles, J. E. y M. A. Lugo-López, 1961. Use of allyl alcohol as a preemergent weedkiller in coffee seedbeds. J. Agric. Univ. P.R. 45 (2):112-115.

Boneta-García, E. y M. A. Lugo-López, 1962. Losses of sucrose in cut cane kept under shade or sun for different periods. J. Agric. Univ. P.R. 46 (3):189-194.

Acevedo-Ramos, G., E. Hernández-Medina y M. A. Lugo-López, 1963. Effect of filter-press cake on crop yields and soil properties. Compost Sci. 3 (4):34-38.

Lugo-López, M. A., 1963. Características del suelo que determinan su resistencia o susceptibilidad a la erosión. Revista de Agricultura de Puerto Rico 50 (2):91-97. 
Lugo-López, M. A., 1966. Highlights of the Water Resources Program at the Agricultural Experiment Station of the University of Puerto Rico. Proc. First Conf. on Water Resources in Puerto Rico.

Hernández-Medina, E. y M.A. Lugo-López, 1967. Observations on the response of Gros Michel banana plants in sand culture to different proportions of various cations and anions. J. Agric. Univ. P.R. 51 (4):309-315.

Lugo-López, M. A. y F. Abruña, 1967. Importancia del conocimiento de los suelos en la planificación agrícola. Revista de Agricultura de P.R. 54 (1-2):58-74.

Hernández-Medina, E. y M. A. Lugo-López, 1968. Plantain production as influenced by magnesium and minor elements. Proc. Caribbean Food Crops Society 6:92-94.

Hernández-Medina, E., J. Vélez-Santiago y M. A. Lugo-López, 1968. The effect of liming on the root development of the West Indian Cherry. Proc. Caribbean Food Crops Society 6:49-51.

Lugo-López, M. A., J. Juárez, Jr. y J. A. Bonnet, 1968. Relative infiltration rate of Puerto Rican soils. J. Agric. Univ. P.R. 52 (3):233-240.

Lugo-López, M. A. y R. Pérez-Escolar, 1968. Functional relationships between the content of particles smaller than $0.05 \mathrm{~mm}$ and $0.002 \mathrm{~mm}$ in size and the plasticity index of soils. J. Agric. Univ. P.R. 52 (4):343-350.

Pérez-Escolar, R. y M. A. Lugo-López, 1968. On the possible significance of high free iron oxide content in Mabí clay, a Vertisol from east-central Puerto Rico. J. Agric. Univ. P.R. 52 (1):47-52.

Pérez-Escolar, R. y M. A. Lugo-López, 1968. Influence of degree of clay mineral crystallization and free iron oxide content on the cation exchange capacity of Catalina and Cialitos soils. J. Agric. Univ. P.R. 52 (2):148-154.

Pérez-Escolar, R. y M. A. Lugo-López, 1968. Nature of aggregation in two tropical soils of Puerto Rico. J. Agric. Univ. P.R. 52 (3):227-232.

Hernández-Medina, E. y M. A. Lugo-López, 1969. Effect of minor nutrient elements and magnesium upon the growth, development and yields of plantains. J. Agric. Univ. P.R. 53 (1):33-40.

Hernández-Medina, E., J. P. Rodríguez y M. A. Lugo-López, 1969. Pruebas preliminares para determinar la posibilidad de cultivar la leguminosa guar (Cyamospis tetragonoloba) como una nueva cosecha potencial para Puerto Rico. Est. Exp. Agric., Univ. P.R. Bol. Misc. Publ. 68.

Lugo-López, M. A., 1969. Prediction of the erosiveness of Puerto Rican soils on basis of the percentage of particles of silt and clay aggregated. J. Agric. Univ. P.R. 53 (3):187-190.

Lugo-López, M. A. y R. Pérez-Escolar, 1969. A mathematical approach to evaluating the influence of various factors on the stability of aggregates in Vertisols. J. Agric. Univ. P.R. 53 (1):57-60. 
Lugo-López, M. A. y R. Pérez-Escolar, 1969. Attempts to explain the variability in the cation exchange capacity of soils in terms of particle size and organic matter levels. J. Agric. Univ. P.R. 53 (4):369-373.

Pérez-Escolar, R. y M. A. Lugo-López, 1969. Availability of moisture in aggregates of various sizes in a typical Ultisol and a typical Oxisol of Puerto Rico. J. Agric. Univ. P.R. 53 (2):113-117.

Pérez-Escolar, R. y M. A. Lugo-López, 1969. Sulfur transformation in a salinesodic soil of the Lajas Valley. J. Agric. Univ. P.R. 53 (2):118-123.

Alers-Alers, S., M. A. Lugo-López y R. Gandía-Caro, 1970. Sugarcane production for 12-, 18 and 24-month cycles under conditions in Puerto Rico. J. Agric. Univ. P.R. 54 (1):110-127.

Hernández-Medina, E., J. Vélez-Santiago y M. A. Lugo-López, 1970. Root development of acerola trees as affected by liming. J. Agric. Univ. P.R. 54 (1):57-61.

Lugo-López, M. A., J. Juárez, Jr. y R. Pérez-Escolar, 1970. Correlation between the rate of water intake of tropical soils at hourly intervals to the 8th hour. $J$. Agric. Univ. P.R. 54 (3):570-575.

Lugo-López, M. A. y M. Capiel, 1972. Seasonal changes in soil temperature at three locations in Puerto Rico, 1963-67. J. Agric. Univ. P.R. 56 (3):307-317.

Alers-Alers, S., F. Juliá y M. A. Lugo-López, 1973. Effect of harvesting sugarcane at 12,14, and 16 months of age upon yields at Isabela. J. Agric. Univ. P.R. 57 (1):1-8.

Lugo-López, M. A., J. J. Bartelli y F. Abruña, 1973. An overview of the soils of Puerto Rico: Classification and physical, chemical and mineralogical properties. Est. Exp. Agric., Univ. P.R. Pub. 79.

Pérez-Escolar, R., J. Juárez, Jr., J. A. Bonnet y M. A. Lugo-López, 1974. Moisture retention and availability in the organic soils of Caño Tiburones. J. Agric. Univ. P.R. 58 (2):225-229.

Badillo, J. y M. A. Lugo-López, 1975. Aplicaciones de nitrógeno aumentan los rendimientos de batatas comerciales. Est. Exp. Agric. Univ. P.R., Adelantos Científicos Núm. 31.

Del Valle, R., Jr., R. H. Fox y M. A. Lugo-López, 1975. Vuelven a lograrse altos rendimientos de habichuelas soyas en Puerto Rico. Est. Exp. Agric. Univ. P.R., Adelantos Científicos Núm. 32.

Del Valle, R., Jr., R. H. Fox y M. A. Lugo-López, 1975. Lack of response of soybeans grown on an Ultisol to broadcast residual and banded P. Fertilizers 13:7382 .

Del Valle, R., Jr., R. H. Fox y M. A. Lugo-López, 1975. Potencial of soybean production in Ultisols and Oxisols of Puerto Rico. Proc. Caribbean Food Crops Society, Trinidad. Pp. 73-82. 
Lugo-López, M. A. y R. Del Valle, Jr., 1975. Intensive culture lead to high plantain yields at low cost. A report to Cornell University, contract AID/csd 2490, Cornell Univ., Ithaca, N.Y.

Lugo-López, M. A. y L. H. Rivera, 1975. Clasificación de los suelos de Puerto Rico. Est. Exp. Agric. Univ. P.R., Adelantos Científicos Núm. 30.

Talleyrand, H. y M. A. Lugo-López, 1975. Es posible obtener buenos rendimientos de batata en la zona de Cidra con aplicaciones de 35 lbs/acre de nitrógeno. Est. Exp. Agric. Univ. P.R., Adelantos Científicos Núm. 28.

Acevedo, G., G. W. Kunze y M. A. Lugo-López, 1976. Características morfológicas, mineralógicas y físico-químicas de los suelos de color oscuro en Puerto Rico. Est. Exp. Agric. Univ. P.R., Adelantos Científicos Núm. 51.

Acevedo, G., G. W. Kunze y M. A. Lugo-López, 1976. Morphological, mineralogical and physico-chemical characteristics of some dark clay soils of Puerto Rico. J. Agric. Univ. P.R. 60 (4):491-507.

Alers-Alers, S. y M. A. Lugo-López, 1976. Se confirma que se obtienen rendimientos más altos de sacarosa y azúcar cuando se cosecha caña a mediados de zafra. Est. Exp. Agric. Univ. P.R., Adelantos Científicos Núm. 53.

Badillo, J. y M. A. Lugo-López, 1976. Evaluación preliminar de las posibilidades de producir papas en la zona noroeste de Puerto Rico. Est. Exp. Agric. Univ. P.R. Adelantos Científicos Núm. 34.

Badillo-Feliciano, J. y M. A. Lugo-López, 1976. Effect of four levels of N, P, K and micronutrients on sweet potato yields in an Oxisol. J. Agric. Univ. P.R. 60 (4):597-605.

Badillo-Feliciano, J. y M. A. Lugo-López, 1976. Effect of planting systems and partial removal of the epidermis of cassava cuttings on growth, yields and root development. J. Agric. Univ. P.R. 60 (4):606-611.

Badillo-Feliciano, J., M. A. Lugo-López y S. Valle-Lamboy, 1976. Performance of Irish potato varieties in an Oxisol in northwestern Puerto Rico. J. Agric. Univ. P.R. 60 (4):612-617.

Lugo-López, M. A., 1976. Movimiento, retención y disponibilidad de agua para las plantas en Oxisols y Ultisols de Puerto Rico. Surco y Cosecha.

Lugo-López, M. A., R. Pérez-Escolar, L. H. Rivera, y J. Juárez, Jr., 1976. Potencial de desarrollo de los suelos más importantes de las llanuras de la cuenca de Yaurel. Est. Exp. Agric. Univ. P.R. Adelantos Científicos Núm. 44.

Lugo-López, M. A., R. Pérez-Escolar y L. R. Rivera, 1976. Major soils of the bottomland and of the Yaurel watershed. Est. Exp. Agric., Univ. P.R. Bol. 243.

Lugo-López, M. A. y L. H. Rivera, 1976. Taxonomic classification of the soils of Puerto Rico, 1975. Est. Exp. Agric., Univ. P.R. Bol. 245.

Talleyrand, H. y M. A. Lugo-López, 1976. Effect of five levels and three sources of $\mathrm{N}$ on sweetpotato yields on an Ultisol. J. Agric. Univ. P.R. 60 (1):9-14. 
Talleyrand, H. y M. A. Lugo-López, 1976. Performance of high yielding corn hybrids Pioneer X-306 B and Funk's G-795 W at high levels of fertilization in the acid and relatively infertile soils (Ultisols and Oxisols) of Puerto Rico. J. Agric. Univ. P.R. 60 (1):132-134.

Talleyrand, H. y M. A. Lugo-López, 1976. Preliminary evaluation of two new high-quality protein Opaque-2 corn varieties on an acid and relatively infertile soil (Ultisol) of Puerto Rico. J. Agric. Univ. P.R. 60 (1):135-137.

Talleyrand, H., R. H. Fox y M. A. Lugo-López, 1976. Se logran altos rendimientos en siembras de maíz Funk's G-795W con aplicaciones de $60 \mathrm{~kg} / \mathrm{ha}$ de nitrógeno en un Ultisol. Est. Exp. Agric. Univ. P.R. Adelantos Científicos Núm. 42.

Talleyrand, H., R. H. Fox y M. A. Lugo-López, 1976. Nitrogen fertilization of a high yielding white kernel corn in Oxisols and Ultisols in Puerto Rico. J. Agric. Univ. P.R. 60 (3):336-343.

Wahab, A., H. Talleyrand y M. A. Lugo-López, 1976. Efecto de la disponibilidad de agua del suelo en un Ultisol y un Oxisol sobre los rendimientos de maíz y sorgo. Est. Exp. Agric. Univ. P.R. Adelantos Científicos Núm. 46.

Wahab, A., H. Talleyrand y M. A. Lugo-López, 1976. Rooting depth, growth and yield of corn as affected by soil water availability in Ultisols and Oxisols. J. Agric. Univ. P.R. 60 (3):316-328.

Wahab, A., H. Talleyrand y M. A. Lugo-López, 1976. Rooting depth, growth and yield of sorghum as affected by soil-water availability in Ultisols and Oxisols. $J$. Agric. Univ. P.R. 60 (3):329-335.

Wolf, J. M., M. Drosdoff y M. A. Lugo-López, 1976. Movimiento y disponibilidad de agua en Oxisols y Ultisols. Est. Exp. Agric. Univ. P.R. Adelantos Científicos Núm. 47.

Alers-Alers, S. y M. A. Lugo-López, 1977. Effect of time of sugarcane harvest on sucrose content and sugar yield. J. Agric. Univ. P.R. 61 (1):77-81.

Badillo-Feliciano, J. y M. A. Lugo-López, 1977. Sweet potato production in Oxisols under a high level of technology. Est. Exp. Agric., Univ. P.R. Bol. 256.

Del Valle, R., Jr., R. H. Fox y M. A. Lugo-López, 1977. Response of soybeans grown in an Ultisol to residual broadcast and banded $\mathrm{P}$ fertilizer. J. Agric. Univ. P.R. 61 (2):179-186.

Lugo-López, M. A., 1977. Los suelos de Puerto Rico, Parte III en "Geovisión de Puerto Rico”. Editorial Universitaria, Univ. P.R. pp. 121-58.

Lugo-López, M. A., J. Badillo-Feliciano y L. Calduch, 1977. Producciones de girasol son posibles en Puerto Rico. Est. Exp. Agric. Univ. P.R. Adelantos Científicos Núm. 65.

Lugo-López, M. A., J. Badillo-Feliciano y L. Calduch, 1977. Performance of oilseed sunflower cultivars on an Oxisol in northwestern Puerto Rico. J.Agr. Univ. P.R. 61 (2):200-203. 
Lugo-López, M. A., J., Badillo-Feliciano y L. Calduch, 1977. Response of native white beans, Phaseolus vulgaris, to various $\mathrm{N}$ levels in an Oxisol. J. Agr: Univ. P.R. 61 (4):438-442.

Lugo-López, M. A., J. Badillo-Feliciano y T. W. Scott, 1977. Performance of red kidney and native white beans at three planting distances on an Oxisol in northwestern Puerto Rico. Proc. Caribbean Food Crops Society 14(2):558-563.

Lugo-López, M. A. y L. H. Rivera, 1977. Updated taxonomic classification of the soils of Puerto Rico. Est. Exp. Agric., Univ. P.R. Bol. 258.

Talleyrand, H., R. Pérez-Escolar, M. A. Lugo-López y T. W. Scott, 1977. Utilization of $\mathrm{N}$ from crop residues in Oxisols and Ultisols. J. Agric. Univ. P.R. 61 (4):450-455.

Badillo-Feliciano, J., M. A. Lugo-López y T. W. Scott, 1978. Effect of planting distance on yield and agronomic characteristics of red kidney and native white beans in an Oxisol. J. Agric. Univ. P.R. 62 (2):145-148.

Capiel, M., E. Brenes, M. A. Lugo-López, P. G. Schoch y V. L. Guzmán, 1978. An evaluation of the growth and water consumption rate of grain sorghum (Sorghum bicolor) at four climatic sites in the tropics and subtropics. J. Agric. Univ. P.R. 62 (1):10-28.

Del Valle, R. Jr., T. W. Scott, J. Rodríguez y M. A. Lugo-López, 1978. Response of plantains to banded and broadcast $\mathrm{N}$ and to $\mathrm{P}$ applications at planting and to residual $\mathrm{P}$ on an Ultisol. J. Agric. Univ. P.R. 62 (1):29-38.

Hardin, J., M. A. Lugo-López y R. Pérez-Escolar, 1978. Promiscuous root nodulation on winged beans grown on an Oxisol in Puerto Rico. Trop. Agr. 55 (4):315324.

Lugo-López, M. A., 1978. Informe del Asesor en Suelos Tropicales. Instituto Boliviano de Tecnología Agropecuaria, Trinidad, Beni, Bolivia.

Lugo-López, M. A., 1978. Report on the soils of the Departments of Beni and Pando, Bolivia, U.S. AID Servicios Técnicos del Caribe. Mimeographed report $46 \mathrm{pp}$.

Lugo-López, M. A., R. Pérez-Escolar y T. W. Scott, 1978. Influence of fertilizer and legume crop residues on maize yields. Proc. Caribbean Food Crops Society 15:39-45.

Pérez-Escolar, R. y M. A. Lugo-López, 1978. Effect of depth of lime application on yield of two corn hybrids grown on a typical Ultisol of Puerto Rico. J. Agric. Univ. P.R. 62 (3):203-213.

Pérez-Escolar, R., M. A. Lugo-López y T. W. Scott, 1978. Effect of depth of lime application on yield and foliar composition of soybeans grown on a typical Ultisol of Puerto Rico. J. Agric. Univ. P.R. 62 (3):224-231.

Pérez-Escolar, R., T. W. Scott y M. A. Lugo-López, 1978. Legume and non-legume crop residues as sources of $\mathrm{N}$ in Oxisols and Ultisols. J. Agric. Univ. P.R. $62(4): 361-366$. 
Sotomayor-Ríos, A. y M. A. Lugo-López, 1978. Nitrogen fertilization of sorghum in an Oxisol in northwestern Puerto Rico. J. Agric. Univ. P.R. 62 (4):380-388.

Wahab, A. H., I. Hassan y M. A. Lugo-López, 1978. Performance of twenty cassava cultivars on marginal peats and peaty clays of Guyana. J. Agric. Univ. P.R. $62(4): 343-354$.

Badillo-Feliciano, J., M. A. Lugo-López y T. W. Scott, 1979. Influence of cultivars, $\mathrm{N}$ levels and time of $\mathrm{N}$ application on plant characters, leaf composition and yield of corn grown on an Oxisol. J. Agric. Univ. P.R. 63 (3):273-280.

Del Valle, R., Jr., T. W. Scott y M. A. Lugo-López, 1979. Response of Irish potatoes to various levels of $\mathrm{N}$ and time of $\mathrm{N}$ application on an Ultisol. J. Agric. Univ. P.R. 63 (3):344-350.

Keng, J. C. W., T. W. Scott y M. A. Lugo-López, 1979. Fertilizer management with drip irrigation in an Oxisol. Agron. J. 71 (6):971-980.

Pérez-Escolar, R. y M. A. Lugo-López, 1979. Effect of soil pH and related acidity factors on yield of plantains (cv. Maricongo) grown on Los Guineos clay, an Ultisol. J.Agric. Univ. P.R. 63 (1):22-26.

Wahab, A. H., M. A. Lugo-López y T. W. Scott, 1979. Exploratory tests on mineralization of organic phosphorus in an Ultisol. Proc. Caribbean Food Crops Society 16:127-129.

Badillo-Feliciano, J. y M. A. Lugo-López, 1980. Differential response of corn and sweet potatoes to $\mathrm{Zn}$ applications on an Oxisol in northwestern Puerto Rico. $J$. Agric. Univ. P.R. 64 (4):482-488.

Del Valle, R., Jr., M. A. Lugo López y J. W. Scott, 1980. Effect of wire support on pod yield of winged beans (Psophocarpus tetragonold). J. Agric. Univ. P.R. 64 (2):211-218.

Lugo-López, M. A., 1980. Sugarcane production at CALNU: Present situation and perspectives. Multinational Agribusiness Systems, Inc. Mimeographed report $46 \mathrm{pp}$.

Lugo-López, M. A., 1980. Sweet sorghum as an energy crop. Multinational Agribusiness Systems, Inc. Mimeographed report $25 \mathrm{pp}$.

Lugo-López, M. A., W. Carrera-Murillo y J. Bauzá, 1980. Tropeptic Haplustox: Major soils of the plains of Riberalta-Guayaramerín in northeastern Bolivia.J. Agric. Univ. P.R. 64 (4):391-399.

Lugo-López, M. A. y L. H. Rivera, 1980. Updated taxonomic classification of the soils of the U.S. Virgin Islands. J. Agric. Univ. P.R. 64 (2):131-137.

Lugo-López, M. A., Pérez-Escolar, R. y R. Del Valle, 1980. Uso de residuos de cosechas como fuentes alternas de nitrógeno. Est. Exp. Agric. Univ. P.R. Adelantos Científicos Núm. 96. 
Wahab, A. y M. A. Lugo-López, 1980. An approach to minimize Al toxicity in U1tisol through organic matter additions. J. Agric. Univ. P.R. 64 (1):1-8.

Wahab, A. H. y M. A. Lugo-López, 1980. Yield response of cassava (Manihot esculenta Crantz) to one and two banded fertilizer applications on a limed Guyana peaty clay soil. J.Agric. Univ. P.R. 64 (2):190-193.

Badillo-Feliciano, J. y M. A. Lugo-López, 1981. An attempt to evaluate the effect of varying time intervals between liming and cropping on an Oxisol. J. Agric. Univ. P.R. 65 (2):83-89.

Del Valle, R., Jr., T. W. Scott y M. A. Lugo-López, 1981. Variable response of food crops to banded and broadcast residual fertilizer P on an Ultisol. J. Agric. Univ. P.R. 65 (2):171-189.

Keng, J. C. W., T. W Scott y M. A. Lugo-López, 1981. Fertilizer for sweet pepper production under drip irrigation in an Oxisol in northwestern Puerto Rico. $J$. Agric. Univ. P.R. 65 (2):123-128.

Lugo-López, M. A., 1981. Observations on the soils of the Department of Pando (Bolivia) and their productive potential. J. Agric. Univ. P.R. 65 (2):192-193.

Lugo-López, M. A., 1981. Soil fertility in the tropics with emphasis on Puerto Rico. First Conf. on Transference of Fertilizer Technology in P.R. TVA, p. 4-6.

Lugo-López, M.A., 1981. Natural resource management project for the Dominican Republic. Servicios Técnicos del Caribe. Mimeographed report 78 pp.

Lugo-López, M. A. y R. Abrams, 1981. High yields of non-fertilized protein-rich pigeonpeas on tropical soils of low inherent fertility of Puerto Rico: An explanation of a paradox. J. Agric. Univ. P.R. 65 (1):21-28.

Lugo-López, M. A. y F. Abruña, 1981. Significance of the presence of potassium bearing feldspars and micas in some soils of Puerto Rico. Univ. P.R. Agric. Exp. Sta. Bull. 265.

Lugo-López, M. A., F. Abruña y R. Pérez-Escolar, 1981. The role of crop and industrial residues on erosion control, properties and productivity of some tropical soils of Puerto Rico. Univ. P.R. Est. Exp. Agric. Univ. P.R. Bol. 266.

Lugo-López, M. A. y M. Antoni, 1981. A practical and simple graphical model to appraise the occurrence of dry spells in the humid tropics. J. Agric. Univ. P.R. 65 (3):264-268.

Lugo-López, M. A. y J. Bauzá-Salas, 1981. Cacao production on well-drained soils along the banks of the Mamoré River on northwestern Bolivia. J. Agric. Univ. P.R. 65 (3):309-310.

Lugo-López, M. A., M. Capiel, L. H. Rivera y G. Acevedo, 1981. Some Aquic Tropudalfs in the vicinity of Villa Banzer and San Carlitos in northeastern Bolivia. J. Agric. Univ. P.R. 65 (4):385-394.

Lugo-López, M. A. y R. Pérez-Escolar, 1981. Mungbean: A versatile crop with potential under conditions in Puerto Rico. J. Agric. Univ. P.R. 65 (3):304-308. 
Lugo-López, M. A., R. Pérez-Escolar y R. Del Valle, 1981. Winged beans as a potential food and green manure crop under conditions in Puerto Rico. J. Agric. Univ. P.R. 65 (1):75-78.

Lugo-López, M. A., J. M. Wolf y R. Pérez-Escolar, 1981. Water loss, intake, movement, retention and availability in tropical soils of Puerto Rico. Est. Exp. Agric. Univ. P.R. Bol. 264.

Vélez-Santiago, J., A. Sotomayor-Ríos y M. A. Lugo-López, 1981. Potential of Stylosanthes guianensis as a forage crop in the humid mountain region of Puerto Rico. J. Agric. Univ. P.R. 65 (3):232-240.

Wahab, A. H., M. A. Lugo-López y T. W. Scott, 1981. Mineralization of organic phosphorus in an Ultisol. J. Agric. Univ. P.R. 65 (3):195-204.

Keng, J. C. W., T. W. Scott, G. Levine y M. A. Lugo-López, 1982. Wetting patterns and associated $\mathrm{P}$ distribution under drip emitters in two Oxisols. Trop. Agric. 59 (3):214-220.

Lugo-López, M. A., 1982. Pigeonpeas (Cajanus cajan Millsp.): A valuable crop of the Tropics. Special Publ. Coll. Agric. Sciences. Univ. P.R., Mayagüez Campus. $123 \mathrm{pp}$.

Lugo-López, M. A. y G. Acevedo, 1982. K values of the soils of Puerto Rico. J. Agric. Univ. P.R. 66 (4):311-312.

Pérez-Escolar, R. y M. A. Lugo-López, 1982. Potencial del mosto como abono para forrajeras. Est. Exp. Agric. Univ. P.R. Adelantos Científicos Núm. 99.

Badillo-Feliciano, J. y M. A. Lugo-López, 1983. Exploratory tests on possible injurious aftereffects of pigeon peas on subsequent crops. J. Agric. Univ. P.R. 67 (2):171-173.

Lugo-López, M. A., 1983. Agricultural evaluation of the Dubreuil, Marigot and Thomazeau irrigation projects in Haiti. A report to U.S. AID.

Lugo-López, M. A., 1983. Evaluation of the Natural Resources Conservation project in Costa Rica. A report to U.S. AID.

Lugo-López, M. A., 1983. Evaluation of the irrigation component of the Integrated Agricultural Development Project No. 521-0078. U.S. AID, Haiti.

Silva, J., M. A. Lugo-López, R. Inglés y J. Dieste, 1983. Anthills in sugarcane fields of northwestern Uruguay. J. Agric. Univ. P.R. 67 (3):335-337.

Lugo-López, M. A., J. P. Carnelli, G. Acevedo y L. H. Rivera, 1984. Major soils of the Area of Bella Unión in northwestern Uruguay. J. Agric. Univ. P.R. 68 (2): 199-218.

Lugo-López, M. A., 1984. Programa de incentivos para la utilización y conservación de los recursos naturales de Costa Rica. Mim. Report, U.S. AID, Costa Rica. 42. p.

Lugo-López, M. A., 1984. Relaciones suelo-agua-planta en Oxisols y Ultisols de los trópicos húmedos. Revista del Colegio de Agrónomos de Puerto Rico, JulioSeptiembre. 
Tirado, G. y M. A. Lugo-López, 1984. Erosion in the hillsides of the Dominican Republic. J. Agric. Univ. P.R. 68 (1):117-119.

Lugo-López, M. A., 1985. Morphological, physical and chemical properties of major soils from Calagua in northwestern Uruguay. Soil Sci. Soc. Amer. J. 49.

Lugo-López, M. A., 1985. Pérdidas post-cosecha en raíces y tubérculos. Revista del Colegio de Agrónomos de Puerto Rico.

Lugo-López, M. A., 1985. Importancia de los residuos de cosechas en los suelos de Puerto Rico. Revista del Colegio de Agrónomos de Puerto Rico.

Lugo-López, M.A., 1985. Propiedades hídricas de algunos suelos de Puerto Rico. Revista del Colegio de Agrónomos de Puerto Rico.

Lugo-López, M. A., 1985. Soil erosion in various countries of the Caribbean Ba$\sin$. In: Erosion and soil productivity. Proc. Nat. Symposium on erosion and soil productivity. Amer. Soc. Agric. Eng., p. 288.

Lugo-López, M. A., M. J. Taylor y A.H. Wahab, 1985. Potential of some small irrigation systems in Haiti. J. Agric. Univ. P.R. 69 (3):445-448.

Lugo-López, M. A. y J. Villarubia-Cruz, 1985. Observations on the physical geography and agriculture of the Río Nosara watershed in the Nicoya Peninsula of Costa Rica. J. Agric. Univ. P.R. 69 (3):449-450.

Lugo-López, M. A. y J. Villarubia-Cruz, 1985. Conflict in land use in the Puriscal area of the Río Parrita watershed in southwestern Costa Rica. J. Agric. Univ. P.R. 69 (3):451-454.

Reynolds, C. A., A. Wahab y M. A. Lugo-López, 1985. K values of the soils of the Acul Watershed in Haiti. J. Agric. Univ. P.R. 69 (3):441-444.

Wahab, A. H., P. Aitken-Soux, I. Johnson, C. Paniagua, B. M. Woo, H. Murray, J. Dehaney y M. A. Lugo-López, 1985. Multiple cropping in the hillsides of Jamaica. J. Agric. Univ. P.R. 69 (3):273-282.

Wahab, A. H., M. A. Lugo-López, B. M. Woo, F. Rosales y J. Dehaney, 1985. Alternatives to bench terraces on the hillsides of Jamaica: I. Soil losses. J. Agric. Univ. P.R. 69 (3):255-264.

Wahab, A. H., E. Montaque-Gordon, J. Deharey, A. L. Wright y M. A. Lugo-López, 1985. Performance of eleven dry bean cultivars (Phaseolus vulgaris) over two successive seasons on the hillsides of Jamaica. J. Agric. Univ. P.R. 69 (3):245-254 .

Wahab, A. H., B. M. Woo, F. Rosales, J. Dehaney y M. A. Lugo-López, 1985. Alternatives to bench terraces on the hillsides of Jamaica: II. Cropping systems and yields. J. Agric. Univ. P.R. 69 (3):265-272.

Wright, A. L., A. H. Wahab, H. Murray y M. A. Lugo-López, 1985. Preliminary trials of six red bean (Phaseolus vulgaris L.) cultivars on an Ultisol in Jamaica. J. Agric. Univ. P.R. 69 (3):239-244. 
Lugo-López, M. A., F. Abruña, J. Vicente-Chandler, H. Irizarry, J. Badillo, J. Rodríguez y E. Rivera, 1986. Comparative response to liming of various non-traditional export crops grown in Ultisols and Oxisols of the Caribbean. Proc. Caribbean Food Crops Society 22:254-260

Abruña, F. y M. A. Lugo-López, 1987. Restoration of productivity in tropical eroded soils under appropriate management. J. Agric. Univ. P.R. 71 (1):1322.

Lugo-López, M. A., 1987. Productividad de los suelos ¿mito o realidad? Diálogo $1(8): 40$.

Wahab, A., M. A. Lugo-López y G. Acevedo, 1987. Soil erosion in southeastern Haiti. J. Agric. Univ. P.R. 71 (2):239-240.

Lugo-López, M. A., 1989. Summary of research priorities by commodity group. In: Alternative agricultural enterprises for the Caribbean and Pacific Basins. Ed. Dewayne L. Ingram, Univ. Florida. pp. 245-7.

Goyal, M. R., K. H. Solomon, H. Ruiz-Giraldo y M. A. Lugo-López, 1990. Los sistemas de riego. In: Manejo de riego por goteo. Goyal, M. R. (Ed.). Servicio de Extensión Agrícola, Univ. P.R. pp. 101-141.

Lugo-López, M. A. y V. A. Snyder, 1990. Consideraciones básicas sobre la relación suelo-planta-agua. In: Manejo de riego por goteo. Goyal, M.R. (Ed.). Servicio de Extensión Agrícola, Univ. P.R. pp. 1-26.

Lugo-López, M. A., 1991. The coefficient of linear extensibility of major soils of Puerto Rico. Proc. Caribbean Food Crops Society 26:584-592.

Lugo-López, M. A., 1992. Review of soil organic matter research in Puerto Rico. In: Organic carbon sequestration in the soils of Puerto Rico. Beinroth, F. H. (Ed.). Univ. P.R. and USDA Soil Conservation Service. pp. 33-56.

Lugo-López, M. A., 1992. Recommendations for future soil carbon research in Puerto Rico. In: Organic carbon sequestration in the soils of Puerto Rico. Beinroth, F. H. (Ed.). Univ. P.R. and USDA Soil Conservation Service. pp. 63-67.

Lugo-López, M. A., 1992. Overview of soil organic matter research in Puerto Rico. Proc. Caribbean Food Crops Soc. 28:595.

Lugo-López, M. A., M. González-Román y J. Arroyo-Aguilú, 1992. Plan de Desarrollo del Programa de Investigación. Estación Experimental Agrícola, Recinto Universitario de Mayagüez.

Lugo-López, M. A., F. H. Beinroth y G. Acevedo, 1993. Oxisols and Ultisols of Puerto Rico. Proc. Caribbean Food Crops Society 29:337.

Lugo-López, M. A., F. H. Beinroth y G. Acevedo, 1994. Soil diversity in Puerto Rico. Proc. Caribbean Food Crops Society 30:390.

Lugo-López, M. A. y F. Abruña, 1995. Magnitude of soil losses throughout the Caribbean. J. Agric. Univ. P.R. 79 (1-2):89-90. 
Lugo-López, M. A., F. H. Beinroth, R. L. Vick, G. Acevedo y M. A. Vázquez, 1995. Updated taxonomic classification of the soils of Puerto Rico, 1994. Univ. P.R. Agric. Exp. Sta. Bull. 294. 21 pp.

Lugo-López, M. A., 1995. El Valle de Lajas: 50 años después. Trabajo presentado en el Simposio sobre terrenos públicos forestales y agrícolas. Recinto Universitario de Mayagüez, Univ. P.R.Acta Científica 9 (57-69):1.

Vázquez, M. A., V. A. Snyder, M. A. Lugo-López y F. H. Beinroth, 1995. Carbon sequestration in tropical soils as a function of edaphic and environmental factors. Proc. Caribbean Food Crops Society 31:195-96.

Lugo-López, M. A., F. H. Beinroth, C. L. Santiago y G. R. Brannon, 1998. Updated taxonomic classification of the soils of the US Virgin Islands, 1997. Univ. P.R. Agric. Exp. Sta. Bull 297.

Sotomayor-Ramírez, D. y M. A. Lugo-López, 1999. K values of the soils of the U.S. Virgin Islands, Haiti and Puerto Rico. Proc. Caribbean Food Crops Society 35:97-99.

Lugo-López, M. A., D. Sotomayor-Ramírez, G. Acevedo y J. Escudero, 2000. Caño Tiburones: The return to a natural reserve after almost 100 years. Proc. Caribbean Food Crops Society 36:231. 